\title{
Basic Outline of the Problem of the "Ageing Population of Farmers" in the Czech Republic
}

\author{
L. Zagata, Š. Hádková, M. Mikovcová
}

Department of Humanities, Faculty of Economics and Management, Czech University of Life Sciences Prague, Czech Republic

\begin{abstract}
Anotace
Problém stárnutí populace farmářů je často zmiňován v evropské diskusi o udržitelném vývoji zemědělství a na daný problém reaguje celá řada politických opatření včetně poslední reformy společné zemědělské politiky EU. Cílem článku je konceptualizovat a empiricky zmapovat problém stárnutí populace farmářů v České republice. S využitím sekundární analýzy dat jsou popsány základní trendy týkající se věkové struktury farem včetně srovnání hlavních parametrů farem u mladších a starších zemědělců. Výsledky studie naznačují, že Česká republika patří mezi země, které nejsou tolik stiženy problémem stárnutí populace farmářů a rozdíly mezi farmami mladších a starších zemědělců nejsou tak výrazné jako v zahraničí. Hodnocení celého problému je však částečně zkresleno metodikou výběru farem, kterou aplikuje Eurostat.
\end{abstract}

\section{Klíčová slova}

Mladí zemědělci, sekundární analýza, Eurostat, sociální udržitelnost, reforma CAP.

\begin{abstract}
The problem of the ageing population of farmers is often mentioned in European discussion on the future sustainability of Agriculture and is addressed by several policy measures including those belonging to the new CAP reform. The goal of this paper is to conceptualise and empirically map the problem of ageing in the Czech Republic. Using secondary data analysis, the paper outlines the basic trends related to changes in the age structure of farmers, including the main parameters of the young and older farmers' holdings. Findings of the study suggest that the Czech Republic belongs among the group of countries which is not so much affected by the problem of ageing and that the differences between farms run by young and older farmers are not as large as in other European countries. Evaluation of the problem is partly distorted by the survey methods used by Eurostat.
\end{abstract}

\section{Key words}

Young farmers, secondary analysis, Eurostat, social sustainability, CAP reform.

\section{Introduction}

"Who will feed us?" This question is discussed in debates on the ageing population of farmers in the Czech Republic and other European countries (Balabánová, 2012; Bika, 2007; DGIP, 2012). The average age of farmers is increasing due to the minimal presence of younger entrepreneurs in the agricultural sector. Available statistics show that approximately every second farm $(53.1 \%)$ in Europe is managed by a farmer aged over 55 years, and almost one-third of all farms $(29.6 \%)$ has a holder aged over 65 years. In contrast, young farmers (in the under-35 age category) manage a relatively smaller proportion of farms (7.5\% of all farms in EU member countries). This raises the aforementioned concerns about the social sustainability of farming, and even concerns about the future ability of the agricultural sector to fulfil its basic societal purpose.

The problem of ageing has also been accentuated in the CAP reform, which took into account the need for a generational renewal on farms (ENRD, 2014a; ENRD, 2014b). The additional payment to young farmers (under 40 years of age, for the period of five years after setting up a new business) has become one of the most important measures intended to facilitate the entrance of young people into Agriculture (European Commission, 2014; European Parliament, 2014).

The problem of ageing as such is comprised 
of several different aspects. The main goal of this paper is to review what is known about the problem of the ageing population of farmers in the Czech Republic. More specifically, it seeks to provide answers to the following questions:

1. How urgent is the problem of the ageing population of farmers in the Czech Republic with respect to recent changes in the age structure of farm holders?

2. What structural features are retained by agricultural holdings managed by young farmers?

3. What are the implications of the problem of ageing for the Czech agricultural sector?

The above-mentioned questions are investigated with the use of secondary data analysis. Prior to a presentation of the empirical results, a conceptual framework is set out to review the main findings in the academic literature and policy documents.

\section{Conceptual framework}

The problem of ageing in Agriculture is associated with two basic phenomena:

(1) increased proportion of older employees in the labour structure; and/or

(2) increased proportion of older farmers (i.e. sole holders) in the age structure of agricultural holders.

The first perspective points out the problem of ageing within the agricultural labour force, while the second perspective is associated with the problem of the ageing population of farmers as such. The European discourse aimed at the issue of ageing in Agriculture corresponds with the second perspective. The increasing proportion of older farmers, together with the decreasing proportion of young farmers, is thus viewed as a key point in the problem of ageing in Agriculture. Such a viewpoint is also applied in our analysis.

The key indicators used for investigating the problem of ageing come from the Farm Structure Surveys and Agricultural Census organised by Eurostat (Eurostat, 2013a; Eurostat, 2013b). These surveys encapsulate the basic demographic variables of sole farm holders, including age. In this way, farmers are classified in the following age intervals: under 35 years, $35-44,45-54$, $55-64$, over 65 years. Representatives of the first age category are considered as 'young farmers', and 'older farmers' are thus associated with the last age category.

However, Zagata and Sutherland (2014) challenged the assessment of the "young farmer problem" at the European level. One of the reasons is that EU member countries have such different agricultural sectors that an international comparison of age structure is distorted. At the same time, they argue that it is not clear what ratio of younger and older farmers in the population actually implies the existence of a problem threatening the functions of the agricultural sector.

According to the findings of these authors, it is possible to divide European countries into two groups. The first is formed by countries with a relatively high proportion of young farmers in the population, outnumbering the proportion of older farmers. This group includes countries such as Poland and Austria, where $11 \%$ of young farmers (i.e. those under 35 ) manage cca $15 \%$ of all agricultural holdings, while older farmers (i.e. those aged $65+$ ) manage less than $10 \%$ of agricultural holdings.

In contrast to this, the second group of countries has a high proportion of farms run by older farmers, at the expense of younger farmers. Examples include Portugal and Greece, where 5\% of young farmers manage approximately $3 \%$ of all holdings, while older farmers manage a much higher proportion of farms. In Portugal, this is $47 \%$ i.e. almost half of all farms in the country, while in Greece it is every third farm (33\%). European countries thus significantly vary in the age structure of their farmers and the problem of ageing in Agriculture varies in its urgency.

Public discourse in the Czech Republic includes only sporadic arguments about the ageing population of farmers. Arguments used during this debate draw mostly on the European statistics and consider the problem of ageing as part of a pan-European phenomenon (Balabánová, 2008; Balabánová, 2011).

The Czech discussion of the ageing problem often includes arguments about the ageing of agricultural employees (Deník, 2014). What is considered as the key problem is the lack of agricultural experts, due to the growing share of employees in the oldest age group. However, the ageing population of farmers, i.e. the second approach to the problem, is overlooked. Specific illustration is provided by the annual reports (the so-called Green Reports) published by the Czech Ministry of Agriculture. 
The Report for the year 2012 claims that "ageing in Agriculture is considered a problem in most European countries." (MZe, 2014: 145). This is supported by statistics describing the changes in the age structure of labour forces in Agriculture.

It is possible to hypothesise that this approach is a historical continuation of the former approach to Agriculture. Studies investigating the structure of labour forces in Agriculture were typically conducted together with stratification studies, which did not take into account the position of the main sole holders of farms. Due to the fact that this approach does not match the framework of the ongoing European discourse (Calus et al., 2008; Mann, 2007; Glauben et al., 2009; Gonzáles et al., 2001; Symes, 1990), it is not possible to evaluate the situation objectively in the Czech Republic. What is more, to our knowledge, there is a shortage of academic publications dealing with the topic of the ageing population of farmers, with only a few exceptions (e.g. Boháčková, Hrabánková, 2011). The 'young farmer' problem is in the European discourse very closely related to issue succession (Burton, 2006; Burton et al., 2005; Fischer et al., 2014), and new entrants (Ingram et al. 2011).

\section{Materials and methods}

The main source of data is the structural survey conducted by the EU member states within Regulation 1166/2008 (Eurostat 2013a). The survey is based on a sample of farms and is repeated every 3 to 4 years. Once per decade, the survey focuses on the entire population of farmers in the form of a census.

The basic unit of analysis is an agricultural holding, which represents an independent technicoeconomic unit, individually managed and focused on agricultural production. The survey includes only holdings that have at least 1 ha of UAA (utilised agricultural area), or smaller holdings with a market production that goes beyond a set level. Besides the main variables of production, data are also collected on the education, gender and age of farmers. Since this dataset is the generally used source of information, the Eurostat's methodological approach forms the basic framework for analysis and evaluation of the entire problem. One of the direct consequences is, for instance, the definition of 'young' and 'older' farmers based on the age intervals used in their survey. 'Young farmers' are therefore the sole main holders in the under-35 age category, in spite of the fact that this definition is not universal and varies from the definition of 'young farmers' included in policy measures. For example, Measure 112 of 2007-2013: 'Setting up young farmers' views young farmers as those who are under 40 years of age.

This study focuses on the basic trends in this area as they developed between 2005 and 2010, i.e. the period after the Czech Republic joined the EU, and also the time points at which the farm structure survey was carried out. Analysis of the time series data is limited due to the low compatibility of each dataset. This problem applies mainly to the data for the Czech Republic, which show a significant decrease in the number of agricultural holdings. Due to changes in definitions of the basic statistical unit, the number of farms in the Czech Republic dropped from 39400 farms in 2007 to 22860 farms in 2010. Such a rapid decline does not reflect a decrease in the numbers of agricultural businesses, but clearly results from the changes in survey methods, in particular from the increased threshold level for agricultural holdings from 1 ha to 5 ha. The official dataset provided by Eurostat does not enable transformation of the datasets from different years to the same baseline. The aforementioned limitation represents important contextual information that we took into account during the analysis and interpretation of the results.

\section{Results and discussion}

\section{a) Evidence about young farmers in the Czech} Republic

In 2005 there were 42450 farms registered in the Czech Republic. According to the 2010 survey, the number of holdings decreased by $45.9 \%$ (39 400 farms in 2007 and 22860 farms in 2010). This declining trend affected absolute figures for the age categories of farmers "under 35 years" and "65+". The relative proportion of young farmers decreased by $36.4 \%$ (from 4200 farms in 2005 to 2670 farms in 2010) and the category of older farmers decreased by $58.6 \%$ (from 7050 farms in 2005 to 2920 farms in 2010). However, the relative proportion of these age categories was not significantly decreased, as shown in Table 1. Young farmers managed approximately $10 \%$, while older farmers managed approximately $15 \%$ of all agricultural holdings in the Czech Republic.

It is important to mention that the methodology used in the survey has changed over the years. This 
change affected the number of holdings included in the survey due to the different threshold level (for more detailed information, see the explanation in the section "Materials and Methods"). Overall, it is difficult to distinguish between the effects of these changes in methodology and the actual structural changes in the sector.

\begin{tabular}{|c|c|c|c|}
\hline Year & 2005 & 2007 & 2010 \\
\hline Holdings total & 42250 & 39400 & 22860 \\
\hline Less than 35 years & 4200 & 3810 & 2670 \\
\hline$(\%)$ & $9.9 \%$ & $9.7 \%$ & $11.7 \%$ \\
\hline $35-44$ years & 7310 & 6850 & 4730 \\
\hline$(\%)$ & $17.3 \%$ & $17.4 \%$ & $20.7 \%$ \\
\hline 45-54 years & 12080 & 10730 & 6140 \\
\hline$(\%)$ & $28.6 \%$ & $27.2 \%$ & $26.9 \%$ \\
\hline 55-64 years & 11610 & 11210 & 6410 \\
\hline$(\%)$ & $27.5 \%$ & $28.5 \%$ & $28.0 \%$ \\
\hline 65 years or over & 7050 & 6790 & 2920 \\
\hline$(\%)$ & $16.7 \%$ & $17.2 \%$ & $12.8 \%$ \\
\hline
\end{tabular}

Source: Eurostat, 2013a

Table 1: Number of agricultural holdings and their relative shares in the Czech.

The increase in the relative counts of young farmers (up to $11.7 \%$ in 2010 ) needs to be viewed with respect to this context, as well as the decrease in the proportion of older farmers to $12.8 \%$, despite the fact that these changes may indicate a positive trend in generational turnover in Agriculture. It is possible to assume that the changes in methodology have mostly affected the number of farmers in the oldest age category. If one examines the relative proportion of the smallest holdings in 2007 (i.e. the last survey before the radical decrease in the overall number of holdings), one notes that the farms in the size category below 4.9 ha are mostly owned by older farmers. About two-thirds of all holdings in this age category (66.1\%) represent the smallest farms. However, in the case of the young farmers, farms of less than 5 ha represent only one-third of all holdings $(32.0 \%)$. Modification of the survey methodology sorted out a significant proportion of agricultural holdings run by older farmers, which consequently affected the relative representation of the other age groups - a decrease in the percentage of older farmers and an increase in the percentage of young farmers - with no relation to the structural changes in the sector.

Such a radical decline in numbers of holdings did not occur in other EU member states, except Slovakia, where the number of farms decreased by $46 \%$. In Poland, Latvia, the United Kingdom and Bulgaria, the number of holdings decreased by 30 to $40 \%$. The change mostly affected the same age categories as in the Czech Republic.

In 2005, young farmers managed overall 36962 holdings $(6.9 \%$ of all agricultural holdings). The last farm structure survey in 2010 identified 32607 farms in the age category of farmers under $35(7.5 \%)$ and 129701 farms (29.7\%) in the age category of $65+$ years. The numbers of holdings in the marginal age categories were affected by changes in the survey methodology. It is possible to prove that both older and younger farmers probably hold farms in the smallest size category throughout Europe (Zagata and Sutherland, 2015).

\section{b) Size of young farmers' holdings}

According to the surveys conducted between 2005 and 2010, the average size of agricultural holdings in the Czech Republic almost doubled. The growth of the mean value (121 ha in 2005 to 221 ha in 2010) accounts for the fact that the smallest farms were excluded from the sample. The average farm size of young farmers reached 91.5 ha, which means that, between 2007 and 2010, the given value increased by $160 \%$. In the case of the category of older farmers, the increase was even more rapid, reaching $360 \%$. However, a discrete change by $310 \%$ due to the change in survey methodology only occurred between 2007 and 2010 .

For a better understanding of the concentration processes in Agriculture and their effects on the selected age categories, it is also useful to take into account the figures of the overall land. The value of the UAA indicator (Utilised Agricultural Area) presented in Table 2 shows changes in the total volume of land farmed by selected age categories.

\begin{tabular}{|r|r|r|r|}
\hline Year & $\mathbf{2 0 0 5}$ & $\mathbf{2 0 0 7}$ & $\mathbf{2 0 1 0}$ \\
\hline Total UAA (ha & 5126190 & 5032220 & 5065270 \\
\hline Less than 35 years & 245080 & 243520 & 244400 \\
\hline ha/ $\%$ & $4.8 \%$ & $4.8 \%$ & $4.8 \%$ \\
\hline 35-44 years & 2001290 & 608140 & 601330 \\
\hline ha/ $\%$ & $39.0 \%$ & $12.1 \%$ & $11.9 \%$ \\
\hline $\mathbf{4 5 - 5 4}$ years & 1329900 & 2617670 & 2661520 \\
\hline ha/ $\%$ & $25.9 \%$ & $52.0 \%$ & $52.5 \%$ \\
\hline 55-64 years & 1357730 & 1351040 & 1272100 \\
\hline ha/ $\%$ & $26.5 \%$ & $26.8 \%$ & $25.1 \%$ \\
\hline 65 years or over & 192190 & 211860 & 285930 \\
\hline ha/ $\%$ & $3.7 \%$ & $4.2 \%$ & $5.6 \%$ \\
\hline
\end{tabular}

Source: Eurostat, 2013a

Table 2: Overall farmed land and its distribution among age categories of farmers. 
The figures presented above show that the total area of land managed by young farmers has not changed significantly, remaining at the level of 245000 hectares. In the opposite age category - older farmers - the total area of land farmed by older managers rapidly declined by more than 93000 hectares. At the same time, the number of holdings for both age categories decreased significantly (for details, see Table 1).

We can thus argue that the concentration in the agricultural sector-indicated by the increasing size of holdings - probably occurred only among farms registered in the Eurostat survey. Holdings excluded from the sample, those belonging to the smallest size categories, had very little or no effect on the total farmed land, which remained at the same level. However, the decrease in the overall number of holdings resulted in an increase of the average farm size.

In the years 2005 and 2007, the majority of farms managed by young and older farmers were the smallest holdings. Almost one-quarter of all farms managed by young farm holders (930) comprised holdings of less than 2 hectares of land. In 2007, young farmers ran 730 farms in the size category of up to 2 hectares,

\begin{tabular}{|c|c|c|c|}
\hline Year & 2005 & 2007 & 2010 \\
\hline Total & 4200 & 3810 & 2670 \\
\hline \multirow[t]{2}{*}{0 ha } & 130 & 90 & 30 \\
\hline & $3.1 \%$ & $2.4 \%$ & $1.1 \%$ \\
\hline \multirow[t]{2}{*}{ Less than 2 ha } & 930 & 730 & 170 \\
\hline & $22.1 \%$ & $19.2 \%$ & $6.4 \%$ \\
\hline \multirow[t]{2}{*}{$2-4.9$ ha } & 620 & 490 & 110 \\
\hline & $14.8 \%$ & $12.9 \%$ & $4.1 \%$ \\
\hline \multirow[t]{2}{*}{5 - 9.9 ha } & 490 & 440 & 430 \\
\hline & $11.7 \%$ & $11.5 \%$ & $16.1 \%$ \\
\hline \multirow[t]{2}{*}{10 - 19.9 ha } & 540 & 520 & 460 \\
\hline & $12.9 \%$ & $13.6 \%$ & $17.2 \%$ \\
\hline \multirow[t]{2}{*}{20 - 29.9 ha } & 280 & 290 & 260 \\
\hline & $6.7 \%$ & $7.6 \%$ & $9.7 \%$ \\
\hline \multirow[t]{2}{*}{$30-49.9$ ha } & 340 & 360 & 370 \\
\hline & $8.1 \%$ & $9.4 \%$ & $13.9 \%$ \\
\hline \multirow[t]{2}{*}{50 - 99.9 ha } & 370 & 430 & 400 \\
\hline & $8.8 \%$ & $11.3 \%$ & $15.00 \%$ \\
\hline \multirow[t]{2}{*}{100 ha or over } & 480 & 450 & 440 \\
\hline & $11.4 \%$ & $11.8 \%$ & $16.5 \%$ \\
\hline
\end{tabular}

Source: Eurostat, 2013a

Table 3: Farm size categories of young farmers (lesss than 35 years of age). which represented one-fifth of all the young farmers' holdings. In 2010, the proportion of larger holdings increased (as shown in Table 3).

In 2010, most older farmers managed holdings in the size category of $5-9.9$ ha (i.e. 810 farms) and in the size category of $10-19.9$ ha (i.e. 610 farms). In contrast to young farmers, the number of older farmers' holdings grew in each size category (if we disregard the problematic size category of less than $5 \mathrm{ha}$ ). The number of young farmers' holdings slightly increased, but only in the size category of $30-99.9$ ha. The number of farms in other size categories slowly decreased (Table 4).

\section{c) Economic performance of farms}

The importance of young farmers and the generational turnover in Agriculture are not related only to social sustainability, but also to the economic sustainability and competitiveness of the sector. These points are derived from the assumed differences in economic performances of young and older farm managers. This performance can be measured by means of standard indicators, such as UAA (Utilised Agricultural Area), AWU (Annual Work Unit) and SO (Standard Output). The AWU indicator can

\begin{tabular}{|c|c|c|c|}
\hline Year & 2005 & 2007 & 2010 \\
\hline Total & 7050 & 6790 & 2920 \\
\hline \multirow[t]{2}{*}{0 ha } & 170 & 150 & 30 \\
\hline & $2.4 \%$ & $2.2 \%$ & $1.00 \%$ \\
\hline \multirow[t]{2}{*}{ Less than 2 ha } & 3390 & 3130 & 380 \\
\hline & $48.1 \%$ & $46.1 \%$ & $13.00 \%$ \\
\hline \multirow[t]{2}{*}{$2-4.9$ ha } & 1500 & 1360 & 200 \\
\hline & $21.3 \%$ & $20.00 \%$ & $6.8 \%$ \\
\hline \multirow[t]{2}{*}{5 - 9.9 ha } & 800 & 820 & 810 \\
\hline & $11.3 \%$ & $12.1 \%$ & $27.7 \%$ \\
\hline \multirow[t]{2}{*}{$10-19.9$ ha } & 570 & 570 & 620 \\
\hline & $8.1 \%$ & $8.4 \%$ & $21.2 \%$ \\
\hline \multirow[t]{2}{*}{$20-29.9$ ha } & 210 & 220 & 240 \\
\hline & $3.00 \%$ & $3.2 \%$ & $8.2 \%$ \\
\hline \multirow[t]{2}{*}{$30-49.9$ ha } & 150 & 180 & 200 \\
\hline & $2.1 \%$ & $2.7 \%$ & $6.8 \%$ \\
\hline \multirow[t]{2}{*}{50 - 99.9 ha } & 90 & 140 & 140 \\
\hline & $1.3 \%$ & $2.1 \%$ & $4.8 \%$ \\
\hline \multirow[t]{2}{*}{100 ha or over } & 180 & 220 & 310 \\
\hline & $2.6 \%$ & $3.2 \%$ & $10.6 \%$ \\
\hline
\end{tabular}

Source: Eurostat, 2013a

Table 4: Farm size categories of elder farmers (above 65 years of age). 
be used for calculation of the average farm size. The Annual Work Unit indicates the amount of work provided by the farm in terms of the number of full-time employees. Standard Output of an agricultural product denotes the average monetary value of the generated products on the farm per month. The ratio of SO and AWU shows how efficiently the farm transforms work in the output of agricultural products. The ratio of UAA and AWU therefore indicates how many people the farm employs with respect to the farmed area of the holding.

\begin{tabular}{|l|r|r|r|}
\hline & \multicolumn{1}{|l|}{$\begin{array}{l}\text { Under 35 } \\
\text { years of age }\end{array}$} & \multicolumn{1}{l|}{$\begin{array}{l}\text { Above 65 } \\
\text { years of age }\end{array}$} & Average \\
\hline UAA & 90.3 & 81.0 & 152.4 \\
\hline AWU & 2.4 & 3.3 & 4.7 \\
\hline SO & 81876 & 101570 & 168 \\
& & & 513 \\
\hline SO/AWU & 34480 & 30862 & 35672 \\
\hline UAA/AWU & 38.0 & 24.6 & 32.3 \\
\hline
\end{tabular}

Source: Eurostat, 2013a

Table 5: Mean values of the key indicators related to economic performance of farms.

Table 5 reviews the values of the key indicators related to the performance of farms managed by young farmers and older farmers. The figures suggest that the young farmers' holdings on average perform better than the farms of the older farmers. One may note that the young farmers' holdings are generally larger than the older farmers' holdings. However, both age groups remain below the national average, young farmers by about $40 \%$ and older farmers by $53 \%$. Farms of both young and older farmers are not unusual in the quantity of employment provided by their farms with respect to their sizes. Holdings of older farmers offer on average 3.3 work units, while holdings of young farmers offer 2.4 work units. These figures are again much lower than the national average. Despite the fact that the farms of young farmers are larger, the monetary value of their SO of agricultural products is lower. The value of the $\mathrm{SO}$ is indeed much lower than the average value in the Czech Republic. The low value is probably accounted for by the great differentiation in farm size. In the agricultural sector in the Czech Republic there is a greater proportion of large farms than in the case of the studied age groups, whereas these large farms probably generate a higher SO due to the economy of scale.

Farms managed by young farmers are more efficient than farms managed by older farmers. The ratio of the generated output per work unit is only $3 \%$ lower than the national average. This value can be regarded as very high, considering that it is produced on small and mid-size farms. This argument supports the last indicator, which measures work productivity on farms. Holdings of young farmers indicate 38 ha of UAA per one work unit, which is about 13.4 ha more than in the case of older farmers' holdings. Work productivity of young farmers is indeed above the national average of the Czech Republic (32.3 hectares per work unit).

The main argument in the European discussion of the ageing population of farmers is the decreasing proportion of farms managed by young farmers (CEJA 2014). This trend is evident from the Eurostat data related to the 2005 and 2007 surveys. The 2010 survey portrayed a slight increase in the relative proportion of young farmers (from 6.2 to $7.5 \%$ ). Despite the fact that the "young farmer problem" is constructed as a pan-European issue, there are large differences among EU member states. The Czech Republic belongs to the group of countries which is less affected by the problem of the ageing population of farmers. The ratio of holdings managed by young farmers to those managed by older farmers is about $1: 1$ and the proportion of farms managed by older farmers does not go beyond $13 \%$. It is important to note that the figures related to the number of farms and their development might be distorted by changes in survey methods, which excluded several thousand holdings that did not pass the threshold level.

At the same time, it is not clear when the ageing population of farmers will become a problem. When exactly the situation becomes threatening for the social sustainability of the agricultural sector? The proportion of young and older farmers needs to be interpreted within the national context and the roles which these groups of farmers perform in the national economies. Their roles are thus based on the specific type of production of their farms, their size and/or geographic position. The context-sensitive perspective is not always included in the European debate on young farmers.

\section{Conclusion}

1. It is necessary to distinguish precisely between the ageing population of farmers and the ageing population of agricultural workers. The European debate about ageing 
in Agriculture is related to the first perspective only.

2. Exact analysis and evaluation of the situation in the Czech Republic is difficult, due to the methods used in the survey, which resulted in excluding a high number of holdings from the sample.

3. The relative proportion of farms managed by young farmers $(11.7 \%)$ and older farmers $(12.8 \%)$ seems favourable in comparison to other EU member states.

4. Young farmers in the Czech Republic are not concentrated on small farms. The average farm size for the under-35-year-old farmers is 90.3 hectares.
5. Comparison of the economic performance of farms managed by young farmers and those managed by older farmers did not show large differences. Contrary to the European statistics, which suggest that young farmers' holdings are more efficient, the young farmers' holdings in the Czech Republic perform below average. On the other hand, these farms indicate a higher work productivity.

\section{Acknowledgements}

The research leading to these results has received funding from the Czech University of Life Sciences Prague for the CIGA Project "Ageing population of farmers and farm succession in the Czech agrarian sector" (nr. 20141016).

\section{Corresponding author:}

Mgr. Ing. Lukáš Zagata, Ph.D.

Department of Humanities, Faculty of Economics and Management,

Czech University of Life Sciences Prague, Kamýcká 129, Prague 6-Suchdol, 16521, Czech Republic

Phone: +420 224382 195, E-mail: zagata@pef.czu.cz

\section{References}

[1] Balabánová, M. Kdo nás bude živit? Hledají se mladí zemědělci, Společnost mladých agrárníků. March 2013. [Online]. Available: http://www.smacr.cz/zpravy/kdo-nas-bude-zivit-hledaji-se-mladizemedelci/ [Accessed: 18 Oct. 2014].

[2] Balabánová, M. Mladí farmáři chtějí větší podporu v podnikání, Společnost mladých agrárníků. October. 2011. [Online]. Available: http://www.smacr.cz/zpravy/mladi-farmari-chteji-vetsipodporu-v-podnikani/ [Accessed: 18 Oct. 2014].

[3] Balabánová, M. Pomoc pro mladé a malé, Společnost mladých agrárníků. June 2008 [Online]. Available: http://www.smacr.cz/zpravy/pomoc-pro-mlade-a-male/ [Accessed: 18 Oct. 2014].

[4] Bika, Z. The territorial impact of the farmers' early retirement scheme. Sociologia Ruralis. 2007, 47, No. 3, p. 246-272. ISSN 1467-9523.

[5] Boháčková, I., Hrabánková, M. Stárnutí zemědělské populace a generační výměna $v$ členských zemích EU. Acta Universitatis Bohemiae Meridionales, The Scientific Journal for Economics, Management and Trade. 2011, 14, No. 2, p. 45-52. ISSN 0139-8849.

[6] Burton, R., Walford, N. Multiple succession and land division on family farms in the South East of England: a counterbalance to agricultural concentration? Journal of Rural Studies. 2005, 21, No. 3, p. 335-347. ISSN 0743-0167.

[7] Burton, R. J. F. An alternative to farmer age as an indicator of life-cycle stage: The case for a farm family age index. Journal of Rural Studies. 2006, 22, No. 4, p. 485-492. ISSN 0743-0167.

[8] Calus, M., Van Huylenbroeck, G., Van Lierde, D. The relationship between farm succession and farm assets on Belgian farms. Sociologia Ruralis. 2008, 48, No. 1, p. 38-56. ISSN 1467-9523.

[9] CEJA (Conseil Europeen des Jeunes Agriculteurs). CEJA disappointed by lack of targeted support for young farmers in new State Aid rules June 2014 [Online]. Available: http://www.ceja.eu/addnew-post-press-release-category-show/ [Accessed: 18 Oct. 2014]. 
[10] Deník.cz. Sektor zemědělství stárne, ministerstvo chce podpořit mladé, Deník.cz. March 2014. [Online]. Available: http://www.denik.cz/ekonomika/sektor-zemedelstvi-starne-ministerstvo-chcepodporit-mlade-20140330.html [Accessed: 18 Oct. 2014].

[11] DGIP (Directorate-General for Internal Policies). 2012. EU Measures to Encourage and Support New Entrants. Policy Department B Structural and Cohesion Policies. Agriculture and Rural Development. [Online] Available at: http://www.europarl.europa.eu/RegData/etudes/note/ join/2012/495830/IPOL-AGRI_NT(2012)495830_EN.pdf [Accessed 29 July 2014].

[12] ENRD. 2014a. Measure 112 - Setting up of young farmers. Progress snapshot 2013/updated May 2014. [Online] Available at: http://enrd.ec.europa.eu/enrd-static/app_templates/enrd_assets/pdf/ measure-information-sheets/C_Infosheet_112.pdf [Accessed on 3 August 2014].

[13] ENRD. 2014b. Measure 113 - Early retirement. Progress snapshot 2013/updated May 2014. [Online] Available at: http://enrd.ec.europa.eu/enrd-static/app_templates/enrd_assets/pdf/measureinformation-sheets/C_Infosheet_113.pdf [Accessed on 3 August 2014].

[14] European Commission. Delegated acts on the CAP Reform - an explanation of the main elements, Communication department of the European Commission. March 2014. [Online]. Available: http://europa.eu/rapid/press-release_MEMO-14-180_en.htm [Accessed: 18 Oct. 2014].

[15] European Parliament. CAP 2014-2020 tools to enhance family farming : Oppourtunities and limits. [Online] Available: http://www.europarl.europa.eu/RegData/etudes/note/join/2014/529051/IPOLAGRI_NT(2014)529051_EN.pdf [Accessed: 18 Oct. 2014].

[16] Eurostat. Farm Structure Survey. June 2013a. [Online] Available: http:// http://epp.eurostat. ec.europa.eu/portal/page/portal/agriculture/farm_structure [Accessed: 18 Oct. 2014].

[17] Eurostat. Glossary: Farm Structure Survey. September 2013b [Online]. Available: http://epp.eurostat. ec.europa.eu/statistics_explained/index.php/Glossary:Farm_structure_survey_(FSS) [Accessed: 18 Oct. 2014].

[18] Fischer, H. and Burton, R. J. F. Understanding Farm Succession as Socially Constructed Endogenous Cycles. Sociologia Ruralis. 2014, 54, No. 4, p. 417-438. ISSN 1467-9523.

[19] Glauben, T., Petrick, M., Tietje, H. and Weiss, C. Probability and timing of succession or closure in family firms: A switching regression analysis of farm householders in Germany. Applied Economics. 2009, 41, No. 1, p. 45-54. ISSN 0003-6846.

[20] González, J., Benito, C. Profession and identity. The case of family farming in Spain. Sociologia Ruralis. 2001, 41, No. 3, p. 343-357. ISSN 1467-9523.

[21] Ingram, J. and Kirwan, J. Matching new entrants and retiring farmers through farm joint ventures: Insights from the Fresh Start Initiative in Cornwall, UK. Land Use Policy. 2011 28, No. 4, p. 917-927. ISSN 0264-8377.

[22] Mann, S. Tracing the process of becoming a farm successor on Swiss family farms. Agriculture and Human Values. 2007, 24, No. 4, p. 435-443. ISSN 1572-8366.

[23] MZe. Zpráva o stavu zemědělství ČR za rok 2012 - „Zelená zpráva“,2012. February 2014 [Online]. Available: http://eagri.cz/public/web/mze/ministerstvo-zemedelstvi/vyrocni-a-hodnotici-zpravy/ zpravy-o-stavu-zemedelstvi/zelena-zprava-2012.html [Accessed: 18 Oct. 2014].

[24] Symes, D. Bridging the generations: succession and inheritance in a changing world. Sociologia Ruralis. 1990, 30, No. 3/4, p. 280-291. ISSN 1467-9523.

[25] Zagata, L., Sutherland, L. A. Deconstructing the 'young farmer problem in Europe': towards a research agenda. Journal of Rural Studies. 2015, No. 2, p. 39-51. ISSN 0743-0167. DOI 10.1016/j.jrurstud.2015.01.003. 